\title{
Collusive Stability and Corporate Governance: The Case of UK Firms
}

\author{
Suha M. Alawi ${ }^{1}$ \\ ${ }^{1}$ King Abdulaziz University, Jeddah, Saudi Arabia \\ Correspondence: Suha M. Alawi, Assistant Professor of Finance, King Abdulaziz University, Jeddah, Saudi \\ Arabia. E-mail: Salawi@kau.edu.sa
}

Received: April 10, 2018

Accepted: May 16, 2018

Online Published: May 20, 2018

doi:10.5539/ijef.v10n6p174

URL: https://doi.org/10.5539/ijef.v10n6p174

\begin{abstract}
UK firms have been involved in the price fixing crime that results into increased, decreased or even stabilization of the goods and services prices. The study aims to investigate the collusive behavior that is achieved on the basis of dynamics and stability of corporate governance among UK firms. A total of 150 firms have been included in the study. The study has collected information from multiple databases such as BoardsEx, ExecuComp, UK Companies House, Annual Reports and DataStream. It is associated with different databases that include board characteristics, CEO characteristics, and ownership structure between the collusive and non-collusive firms. A significant positive association has been observed between collusive behavior and qualities of corporate governance. Results have been represented as two tailed, showing different observations with their respective means and standard deviation. The study has provided brief summary of descriptive statistics, associated with the collusive behavior of collusive and non-collusive firms, in relation to the ownership structure, board characteristics, and CEO characteristics.
\end{abstract}

Keywords: collusive stability, corporate governance, UK firms

\section{Introduction}

\subsection{Background}

Recently, the engagement of UK firms is increasingly observed in price fixing crime, resulting into the adverse stabilization of the commodity prices. There was an increase of $\$ 2$ billion per year in the penalties enforced on the organizations in the starting of $21^{\text {st }}$ century. US and European Union impose $60 \%$ of the total penalties; while, private suits tend to settle around $40 \%$ of the penalties (Connor \& Helmers, 2007). The relationship built by independently working firms that aim to achieve certain objectives within the explicit agreements is defined as collusive behavior. These agreements help the firms to gain profits by restricting the level of output and controlling the prices. The factors, capable of disturbing the collusive stability, include; the possibility of cheating and entry of new firms in market (Levenstein \& Suslow, 2006).

\subsection{Problem Statement}

The collusive agreements are managed at decreased discount factors to achieve the incentives provisions, when the managers tend to find a smooth path for profits. The competence of shareholders and stakeholders toward high costs is widely observed in increasing the profits of organizations. At the top hierarchical levels, the interplay between the performance-based incentives and collusive agreements is reported throughout the classical model of repeated oligopoly (Buccirossi \& Spagnolo, 2007). The collusive agreements are needed to be enforced by the organization's management; however, actual decision regarding the formation of collusive is taken by the top management. The collusive price fixing agreements need to be formed on the basis of collusive to take up entire agreements. Individuals will be collusive if organizations are keen to provide incentives based on the performance levels and strategies implemented at top level.

\subsection{Relevant Scholarship}

It is necessary to understand the working and impact of collusive formation on the society and economy. The impact of collusive can result in the loss of reputation and high fines; although, it benefits the shareholders and executives during a specific period of operation (Agrawal \& Mandelker, 1990). A war may start among the partners present within a collusive, if they tend to fine exceptional earnings, which may eventually result in decreased overall earning. The decreased strength of board of directors tends to increase the collusive 
participation; therefore, majority of the organizations do not favor to carry out the hard-core activities for establishing collusive agreements (Spagnolo, 2005). According to Lin (2001), a pivotal role of corporate governance is emerged in the transition economies where it transforms their wholesale property rights.

A study conducted by Spagnolo (2005) stated that the joining of collusive is encouraged by the fixing and management incentives as it enlightens collusive behavior and the corporate governance. Moreover, the study has explained the compensation schemes as a significant characteristic of corporate governance that tends to enforce collusive agreements for managing different organizations. Another study conducted by Han (Han, 2010) investigated the impact of employment contracts on the stability of collusive. The study has asserted that the involvement of an organization is essential in collusive agreement since it results into the increasing or decreasing turnover extent of CEO.

Dignam and Galanis (2016) mentioned that increasing costs lessen the attractiveness of collusive behavior. A price war is likely to start among the partners within the collusive if they find exceptional earning. Similarly, Colli and Colpan (2016) identified that exceptional earnings might result in decreased overall earnings. The collusive activities are facilitated by successful collusive that is possessed by the concentrated industries (Bolotova, Connor, \& Miller, 2008). Moreover, Marwaha (2017) stated that two issues have acquired adequate attention including; the possibility of cheating and entry of new firms. The presence of corporate governance might be actualized differently in both collusive and non-collusive firms. Certainly, the role of these attributes become important when associated with the formation and discovery of collusive firms.

Previous studies have investigated the economic consequences related to collusive behavior; however, this study has discussed the collusive behavior associated with the corporate governance. This association is investigated by limited studies. The characteristics of board of directors, ownership structuring, characteristics of CEO, and compensation scheme of CEOs are considered as independent variables reflecting the attributes of corporate governance. Therefore, this study has investigated the association between corporate governance and collusive behavior, which relates to the concerned attributes.

A study utilized sample of 1148 observations in 182 different U.S. collusive firms to evaluate the relationship among different variables of corporate governance, collusive behavior, and product market competition. The findings have indicated that the potential collusive prize fixing agreements includes the direct involvement of CEO and board of directors to get an assumption of significant association between collusive behavior and corporate governance (Gonzalez \& Schmid, 2012). The concept of corporate governance mainly focuses on the firms, their stakeholders, and accountability of the firms. A recent study stated that the shareholding of major UK companies has shrunk within the globalized economy; whereas, the shareholders have dispersed as compared to the previous time (Sikka \& Stittle, 2017). Relinquishment of shareholder model maintain a lasting interest in the well-being of firms and allow stakeholders to be empowered.

The relationship between corporate governance and firms' performance is emerged from the soft aspects that have a tendency to augment the corporate governance quality among different firms. The code committees need to be activated to strengthen the confidence of investors and comply with a specific recommendation (Rose, 2016).

\subsection{Aims and Objectives}

The study aims to investigate dynamics and stability of collusive and corporate governance within the UK firms. It has been shown that paths to attain maximum profit are attained through the documentation of collusive agreements to be accepted at lower discount factors. The study has discussed the remuneration scheme as an important characteristic of corporate governance. The study outcomes are likely to show that collusive stability can be achieved through short-term contract as compared to the long-term contract.

\section{Methodology}

The collusive sample in the present study has been obtained through screening and examining the initial set. The comparison and t-test as a methodology has been used due to the nature of study. As the study aimed to investigate the collusive behavior that is achieved on the basis of dynamics and stability of corporate governance among UK firms. Therefore, comparison approach is helpful to investigate collusive behavior appropriately. The participation of collusive has been investigated on the basis of the benchmark that is set for the recruited firms. The study has created data of around 150 firms that are associated with the formation of collusive. Among the 150 collusive firms, 114 firms were from UK (Table 1). The present study has used several databases for selecting collusive sample and examining different board characteristics, CEO characteristics, and ownership structure between the collusive and non-collusive firms. The information related to the collusive cases has been 
obtained through various departments including; the Department of Justice (DoJ), Competition Commission (CC), European Commission (EC), and Office of Fair Trading (OFT).

The information obtained from these departments was not publically available. It is a considerable task to find relevant information on collusive and its associated firms. Moreover, the study has collected information about financial data and corporate structure from different firms that are operated globally. The study has merely aimed to involve the firms operating collusive since the aim is to examine characteristics of boards of directors of firms. The information was extracted from multiple databases, which include ExecuComp, Annual Reports, BoardsEx, UK Firms House, Fame and DataStream. The characteristics of the boards and CEOs associated with collusive behavior are examined through different variables.

Table 1. Selected collusive firms

\begin{tabular}{cccc}
\hline Description & Identified firms & Excluded firms & Recruited firms \\
\hline Total firms identified & 3200 & - & - \\
Under investigation & - & 37 & 3163 \\
Cases with no history & - & 518 & 2645 \\
Unidentified firms & - & 744 & 1901 \\
Identified collusive firms & - & 1299 & 1901 \\
Collusive firms without at least one UK firm & - & 1220 & 681 \\
Collusive firms outside 1990 - 2000 period & - & 457 & 224 \\
Collusive firms without suitable governance and financial data & - & 74 & 150 \\
Final sample of collusive firms & - & - & 150 \\
\hline
\end{tabular}

\section{Results and Discussion}

Certain variables like CEO characteristics, board characteristics, and ownership structure have been included in the study for supporting the findings. These positions are most likely to be relevant to collusive behavior of different companies. A total of six boards, two ownerships, and eight CEO characteristics have been described. The reliance of internal control environment on market environment, regulatory environment and legal aspects is significantly revealed. In addition, the focus of internal control environment has been relatively important on-board characteristics as compared to the board activities or decisions. This shows the importance of internal control environment for CEO characteristics and static model of board. Therefore, the inclusion of market and legal indices has been made mandatory for examining the interplay between collusive and non-collusive firms. The analysis of board and CEO characteristics is based on the cross-comparison between collusive and non-collusive controlling. The results have shown significant association between collusive behavior and qualities of corporate governance.

The collusive behavior of UK companies has been measured, using the records from 1990 to 2010 regarding their collusive activities and sanctions. The three significant factors including; market environment, legal environment, and internal enforcement characterize the success of collusion (Bolotova et al., 2008). The present study has examined the governance structure of certain firms, involved in the collusive behavior. Thereby, the study has investigated the relationship of collusive behavior and discovery in reference to corporate governance variables, which include CEO and board characteristics. The significance of this relationship among collusive and non-collusive firms turns into the formation of control measures for explaining the legal and market environments.

The present study has examined the interplay from period 1990 to 2010 between collusive firms and non-collusive firms, providing explanation of the characteristics possessed by the board and CEO. In relation to the ownership structure, board characteristics, and CEO characteristics, it has provided a brief summary of descriptive statistics associated with the collusive behavior of collusive and non-collusive firms. A total of 7 directors, who were either female directors or non-executive directors were associated with average board size of collusive firms. As compared to the collusive firms, a total of 5 directors (non-executive and female directors) are involved in the non-collusive firms.

T-test has been used to validate the findings based on the means distributions throughout the collusive and non-collusive firms. The findings have shown that the ratio of a female CEO is lower in collusive firms ( 1 out of 150) as compared to non-collusive firms (35 out of 178). A statistical significant difference has been yielded from the means difference. The findings have shown that the ratio of female CEO is lower in collusive firms as compared to non-collusive firms. These findings are consistent with the findings revealed by Berger, Kick \& 
Schaeck (2014). Present study results depicted that as compared to men, females take inadequate and poor investment decisions and financial risks. The comparison of collusive and non-collusive firms in UK have been presented in table 2 .

Table 2. Comparison between variables

\begin{tabular}{|c|c|c|c|c|c|c|c|}
\hline \multirow[b]{2}{*}{ Category } & \multicolumn{3}{|c|}{ UK Collusive Firms } & \multicolumn{3}{|c|}{ UK Non-Collusive Firms } & \multirow[b]{2}{*}{ T-test (p-value) } \\
\hline & Obs & Mean & STDV & Obs & Mean & STDV & \\
\hline \multicolumn{8}{|c|}{ Independent Variable } \\
\hline \multicolumn{8}{|c|}{ Boards Characteristics } \\
\hline Size & 114 & 5.61 & 3.68 & 135 & 5.09 & 3.51 & 0.26 \\
\hline Duration & 114 & 2.09 & 1.07 & 134 & 2.44 & 1.51 & $0.04 * *$ \\
\hline Age & 114 & 44.72 & 8.09 & 134 & 47.23 & 8.74 & $0.02 * *$ \\
\hline GEN $(\%)$ & 114 & 0.04 & 0.11 & 138 & 0.11 & 0.19 & $0.00 * *$ \\
\hline Ned $(\%)$ & 114 & 0.05 & 0.16 & 138 & 0.98 & 0.15 & $0.05 * *$ \\
\hline Remun & 92 & 0.31 & 1.55 & 92 & 0.12 & 0.17 & 0.25 \\
\hline \multicolumn{8}{|c|}{ Ownership Structure } \\
\hline Outown $(\%)$ & 114 & 0.76 & 0.40 & 138 & 0.67 & 0.44 & $0.08 * *$ \\
\hline FAMCON & 113 & 0.00 & 0.09 & 138 & 0.94 & 0.29 & $0.00 * *$ \\
\hline \multicolumn{8}{|c|}{ CEO Characteristics } \\
\hline CEO tenure & 114 & 8.9 & 0.16 & 138 & 10.4 & 4.81 & $0.01 * *$ \\
\hline CEO age & 114 & 51.2 & 8.19 & 138 & 44.26 & 9.56 & $0.00 * *$ \\
\hline CEO gender & 114 & 0 & 0 & 138 & 0.16 & 0.37 & $0.00 * *$ \\
\hline BOSS & 114 & 0.43 & 0.49 & 138 & 0.26 & 0.44 & $0.00 * *$ \\
\hline Multidirectorship & 114 & 1.69 & 2.48 & 138 & 2.84 & 2.97 & $0.00 * *$ \\
\hline \multicolumn{8}{|c|}{ CEO Compensation } \\
\hline Bonus & 38 & 14.8 & 17.2 & 33 & 7.41 & 1.19 & $0.03 * *$ \\
\hline Share & 38 & 7.64 & 14.8 & 33 & 6.42 & 13.9 & $0.00 * *$ \\
\hline Tcomp & 38 & 64.03 & 52.2 & 33 & 28.4 & 36.3 & $0.00 * *$ \\
\hline \multicolumn{8}{|c|}{ Control Variables } \\
\hline COSTA & 114 & 0.61 & 0.48 & 138 & 0.25 & 0.43 & $0.00 * *$ \\
\hline Saleba & 112 & 6.23 & 55.15 & 135 & 1.05 & 2.00 & 0.27 \\
\hline PPER & 104 & -1.74 & 15.8 & 123 & 9.15 & 33.01 & $0.00 * *$ \\
\hline CURRRATIOB & 110 & 1.41 & 1.07 & 132 & 1.5 & 1.24 & 0.61 \\
\hline HHI & 114 & 0.25 & 0.21 & 138 & 0.17 & 0.16 & $0.00 * *$ \\
\hline
\end{tabular}

Table 3 has depicted the association between distinctive features of collusive and non-collusive firms in UK. The findings have indicated that there is a significant and positive correlation between CEO tenure duration, CEO age and collusive, CEO case and collusive, CEO gender and gender, COSTA and Remun and Tcomp and CEO age. The study has asserted the inclusion or recruitment of women in the collusive firms since only 36 females were working in 328 collusive and non-collusive firms in total. This ratio clearly shows the gender biasness in these firms and allow more preference toward male employees. Poor investment decisions and financial risks are major factors that restrict the employability of females in collusive firms. Despite the concerns exist in collusive firms, it is potentially providing opportunities and benefits to increase globalization and modernization processes with immense information exchange.

Due to modernization and globalization process, the potential benefits and opportunities of collusive behavior have been expanded. It helps in instigating the collusive behavior internationally with immense information retrieval and exchange. The requirement for collusive behavior based on the market information and new opportunities is apparently shown from the association between corporate governance and market competition (Du Plessis, Hargovan, \& Bagaric, 2010). The extent of international competition has been emerged immensely that shows the understanding and models introduced by economists (Grossman, 2004). Thereby, the formation of collusive behavior in the first place has been led by the factors associated with the collusive detection and board characteristics. The constitution of corporate governance is thus significantly relied on its external mechanism (Lin, 2001). 
Table 3. The Spearman's rank-order correlation test (5.5)

\begin{tabular}{|c|c|c|c|c|c|c|c|c|c|c|c|c|}
\hline Variable & CONV & Collusive & Size & Dur & Age & Gen & NED & Remun & CEOten & CEOage & CEOgen & Multidir \\
\hline CONV & 1.00 & & & & & & & & & & & \\
\hline Collusive & $0.90^{*}$ & 1.00 & & & & & & & & & & \\
\hline Size & -0.02 & -0.04 & 1.00 & & & & & & & & & \\
\hline Dur & -0.11 & -0.05 & $0.55^{*}$ & 1.00 & & & & & & & & \\
\hline Age & 0.17 & $0.28 *$ & $0.41^{*}$ & $0.34 *$ & 1.00 & & & & & & & \\
\hline Gen & 0.02 & 0.09 & $0.33^{*}$ & 0.13 & 0.10 & 1.00 & & & & & & \\
\hline NED & -0.09 & -0.04 & 0.00 & -0.21 & 0.03 & 0.12 & 1.00 & & & & & \\
\hline Remun & -0.21 & -0.21 & 0.09 & -0.02 & -0.12 & -0.05 & 0.13 & 1.00 & & & & \\
\hline CEOten & $-0.45^{*}$ & $-0.38^{*}$ & 0.16 & $0.35^{*}$ & -0.16 & 0.22 & 0.02 & 0.21 & 1.00 & & & \\
\hline CEOage & $0.57 *$ & $0.61 *$ & 0.16 & 0.06 & $0.30^{*}$ & 0.02 & 0.08 & 0.09 & $-0.28 *$ & 1.00 & & \\
\hline CEOgen & -0.23 & $-0.25^{*}$ & 0.22 & 0.16 & $0.24 *$ & $0.24 *$ & 0.01 & 0.08 & 0.01 & $-0.28^{*}$ & 1.00 & \\
\hline Multidir & 0.05 & 0.01 & 0.05 & 0.04 & -0.09 & -0.17 & -0.17 & 0.12 & -0.05 & 0.01 & -0.17 & 1.00 \\
\hline BOSS & 0.15 & 0.15 & -0.08 & 0.02 & -0.08 & -0.17 & -0.06 & $-0.24 *$ & $-0.41 *$ & $0.25^{*}$ & -0.14 & 0.01 \\
\hline Bonus & $0.50 *$ & $0.45^{*}$ & $-0.32 *$ & -0.23 & -0.07 & 0.02 & 0.05 & -0.07 & $-0.27 *$ & 0.19 & -0.23 & -0.06 \\
\hline Share & $0.40^{*}$ & $0.38 *$ & -0.04 & -0.02 & -0.12 & -0.03 & 0.10 & -0.21 & $-0.25^{*}$ & $0.32 *$ & -0.16 & 0.03 \\
\hline Tcomp & $0.58^{*}$ & $0.56^{*}$ & $-0.32 *$ & -0.18 & -0.02 & -0.06 & -0.02 & $-0.23 *$ & $-0.40^{*}$ & $0.24 *$ & $-0.27 *$ & -0.04 \\
\hline Outown & -0.12 & -0.06 & 0.05 & 0.01 & -0.07 & 0.00 & 0.14 & -0.03 & 0.16 & -0.09 & $-0.41^{*}$ & -0.06 \\
\hline FAMCON & 0.20 & 0.10 & -0.13 & -0.17 & -0.07 & -0.06 & -0.09 & -0.04 & 0.04 & 0.15 & -0.03 & -0.02 \\
\hline COSTA & -0.08 & -0.17 & 0.00 & -0.05 & $-0.32 *$ & -0.02 & 0.21 & $0.25^{*}$ & $0.28 *$ & -0.04 & -0.12 & -0.03 \\
\hline PPER & $-0.49 *$ & $-0.55^{*}$ & -0.06 & 0.12 & -0.08 & -0.12 & -0.17 & 0.20 & 0.19 & $-0.30^{*}$ & 0.22 & 0.14 \\
\hline Saleb & 0.19 & 0.18 & -0.12 & -0.07 & 0.06 & 0.08 & $0.37 *$ & 0.16 & -0.13 & 0.21 & -0.13 & 0.14 \\
\hline HHI & $0.24 *$ & 0.20 & -0.10 & -0.14 & $-0.28 *$ & -0.17 & -0.18 & 0.07 & 0.01 & 0.05 & -0.18 & 0.02 \\
\hline DoJ & $0.24 *$ & $0.29 *$ & -0.04 & -0.01 & 0.18 & 0.06 & -0.05 & -0.09 & -0.09 & 0.16 & -0.08 & -0.13 \\
\hline UK & 0.19 & 0.15 & $0.32 *$ & -0.13 & 0.02 & 0.02 & 0.15 & $0.34 *$ & $-0.29 *$ & 0.13 & 0.12 & 0.13 \\
\hline Join & $-0.42 *$ & $-0.48^{*}$ & 0.07 & -0.05 & $-0.33^{*}$ & 0.08 & 0.07 & $0.54^{*}$ & $0.49^{*}$ & $-0.35^{*}$ & -0.06 & $0.33^{*}$ \\
\hline CEOcase & $0.73^{*}$ & $0.57 *$ & -0.18 & -0.22 & 0.15 & -0.18 & -0.11 & -0.18 & $-0.52 *$ & $0.32 *$ & -0.15 & 0.09 \\
\hline CEOnum & $0.88^{*}$ & $0.83^{*}$ & -0.18 & -0.19 & 0.20 & -0.13 & -0.11 & $-0.25^{*}$ & $-0.58^{*}$ & $0.49 *$ & -0.22 & 0.03 \\
\hline
\end{tabular}

\section{Conclusion}

This study aimed to focus on the stability and dynamics of collusive and corporate governance within the UK firms. T-test analysis has shown that public firms, unlike private firms are more prone to get involved in the collusive behavior. The study has concluded that the behavior of collusive and non-collusive firms differs in terms of board of directors' characteristics, CEO characteristics, ownership structure, and CEO compensation package. On the contrary, the study lacks to report any significance of monitoring measure in detecting potential collusive menace associated with corporate governance. Previously, significant attempts have been made to overcome the negative consequences of competition law. Therefore, this study has made a conclusive statement towards corporate violation and highly dynamic market conditions to observe the systems of corporate control and corporate activity. The study results have helped to understand the relationship between different features of corporate governance and collusive behavior, providing revelation of practices prevailing in corporate governance.

This study has found several limitations. Firstly, this study has used a mixed method data collection for examining the relationship between collusive stability and corporate governance in UK firms. This allows the researcher to extract the information regarding collusive cases using secondary data whereas variables associated with corporate governance were extracted using primary data. Secondly, this study has merely included UK firms, which gives evidence regarding the selected region rather than discussing the issue internationally. Therefore, it has been recommended that future studies should conduct a comparative analysis by including multiple countries. Lastly, this study is based on quantitative aspects and reported the evidence numerically, which gives merely the extent how stable firms are collusive with respect to corporate governance. However, it has been recommended that future studies should adopt qualitative research design to assess and explore the opinions of stakeholders and board of directors towards the stability of collusive firms with respect to corporate governance. 


\section{Acknowledgements}

The author is very thankful to all the associated personnel in any reference that contributed in/for the purpose of this research. This research holds no conflict of interest. This study is not funded through any source.

\section{References}

Agrawal, A., \& Mandelker, G. N. (1990). Large shareholders and the monitoring of managers: The case of antitakeover charter amendments. Journal of Financial and Quantitative analysis, 25(2), 143-161. https://doi.org/10.2307/2330821

Berger, A. N., Kick, T., \& Schaeck, K. (2014). Executive board composition and bank risk taking. Journal of Corporate Finance, 28, 48-65. https://doi.org/10.1016/j.jcorpfin.2013.11.006

Bolotova, Y., Connor, J. M., \& Miller, D. J. (2007). Factors influencing the magnitude of collusive overcharges: An empirical analysis of food-industry collusives. Agribusiness, 23(1), 17-33. https://doi.org/10.1002/agr.20111

Bolotova, Y., Connor, J. M., \& Miller, D. J. (2008). Factors influencing the magnitude of collusive overcharges: An empirical analysis of the US Market. Journal of Competition Law and Economics, 5(2), 361-381. https://doi.org/10.1093/joclec/nhn025

Buccirossi, P., \& Spagnolo, G. (2007). Corporate governance and collusive behaviour.

Colli, A., \& Colpan, A. M. (2016). Business Groups and Corporate Governance: Review, Synthesis, and Extension. Corporate Governance: An International Review, 24(3), 274-302. https://doi.org/10.1111/corg.12144

Connor, J. M., \& Helmers, C. G. (2007). Statistics on modern private international collusives, 1990-2005. https://doi.org/10.2139/ssrn.1103610

Dignam, A., \& Galanis, M. (2016). The globalization of corporate governance. Routledge.

Du Plessis, J. J., Hargovan, A., \& Bagaric, M. (2010). Principles of contemporary corporate governance. Cambridge University Press. https://doi.org/10.1017/CBO9781139151467

Gonzalez, T. A., \& Schmid, M. (2012). Corporate Governance and Antitrust Behavior. Gallen, Switzerland: Swiss Institute of Banking and Finance, university of St. Gallen.

Grossman, P. Z. (Ed.). (2004). How collusives endure and how they fail: Studies of industrial collusion. Edward Elgar Publishing.

Han, M. A. (2010). Short-term managerial contracts facilitate collusives.

Levenstein, M. C., \& Suslow, V. Y. (2006). What determines collusive success? Journal of Economic Literature, 44(1), 43-95. https://doi.org/10.1257/002205106776162681

Lin, C. (2001). Corporatisation and corporate governance in China's economic transition. Economics of Planning, 34(1), 5-35. https://doi.org/10.1023/A:1017596315273

Marwaha, K. (2017). Corporate governance and whistle blowing in India: Promises or reality? International Journal of Law and Management, 59(3). https://doi.org/10.1108/JJLMA-12-2015-0064

Rose, C. (2016). Firm performance and comply or explain disclosure in corporate governance. European Management Journal, 34(3), 202-222. https://doi.org/10.1016/j.emj.2016.03.003

Sikka, P., \& Stittle, J. (2017). Debunking the myth of shareholder ownership of companies: Some implications for corporate governance and financial reporting. Critical Perspectives on Accounting. https://doi.org/10.1016/j.cpa.2017.03.011

Spagnolo, G. (2005). Managerial incentives and collusive behavior. European Economic Review, 49(6), 1501-1523. https://doi.org/10.1016/j.euroecorev.2004.05.003

\section{Copyrights}

Copyright for this article is retained by the author(s), with first publication rights granted to the journal.

This is an open-access article distributed under the terms and conditions of the Creative Commons Attribution license (http://creativecommons.org/licenses/by/4.0/). 